\title{
SIYYAH ÇAY ÜRETİM ATIKLARINDAN KONSANTRE ÇAY EKSTRAKTI ÜRETİMİNDE KREMA OLUŞUM KOŞULLARININ VE BİLEŞİMİNİN BELİRLENMESİ
}

\author{
Ferhan Balc1-Torun ${ }^{1}$, Kübra Sultan Özdemir ${ }^{2}$, Rukiye Mavuşs ${ }^{3}$, Mehmet Torun ${ }^{1 *}$ \\ ${ }^{1}$ Akdeniz Üniversitesi, Mühendislik Fakültesi, Gıda Mühendisliği Bölümü, Antalya, Türkiye \\ ${ }^{2}$ Konya, Gıda ve Tarım Üniversitesi, Mühendislik ve Mimarlık Fakültesi, Gıda Mühendisliği Bölümü, Konya, \\ Türkiye
}

Geliş / Received: 30.12.2020; Kabul / Accepted: 03.03.2021; Online bask1 / Published online: 11.03.2021

Balc1-Torun, F., Özdemir, K.S., Mavuş, R., Torun, M. (2021). Siyah çay üretim atıklarından konsantre çay ekstraktı üretiminde krema oluşum koşullarının ve bileşiminin belirlenmesi. GIDA (2021) 46(2) 339350 doi: $10.15237 /$ gida. GD20145.

Balc-Torun, F., Özdemir, K.S., Mavus, R., Torun, M. (2021). Determination of cream formation conditions and its composition during production of concentrated tea extract from black tea manufacturing wastes. GIDA (2021) 46(2) 339-350 doi: 10.15237/gida. GD20145.

\section{ÖZ}

Bu çalışmada, Türk siyah çayı işletme atıklardan konsantre çay ekstraktı üretimi gerçekleştirilmiş, üretim sırasında oluşan krema miktarı ve bileşimi ile son ürünün bazı özellikleri belirlenmiştir. Bu doğrultuda en uygun ekstraksiyon koşullarının belirlenmesi amacıyla üç farklı sıcaklık $\left(75,85\right.$ ve $\left.95^{\circ} \mathrm{C}\right), 5$ farklı süre $(15,30$, 45 , 69 ve 90 dakika) ve 2 farklı atık çay/su besleme oranında $(1 / 15$ ve $1 / 20)$ ekstraksiyonlar gerçekleştirilmiştir. Ekstraksiyon çalışmaları en uygun şartların $95^{\circ} \mathrm{C}, 30$ dakika ve $1 / 15$ besleme oranı olduğunu göstermiş ve elde edilen ekstraktın suda çözünür kuru madde miktarı $1.8^{\circ} \mathrm{Bx}$, kafein miktarı 0.45 $\mathrm{g} / 100 \mathrm{~g}$ ve bulanıklık 27.6 NTU olarak ölçülmüştür. Ön konsantre $\left(15^{\circ} \mathrm{Bx}\right)$ edilen ekstraktlarda $4{ }^{\circ} \mathrm{C}$ 'de 12 saat sonunda en fazla miktarda $(1.98 \mathrm{~g} / 100 \mathrm{~mL})$ çay kreması oluşumu gözlenmiş ve kremanın \% 15.88 kafein, $\% 17.08$ protein, $\% 8.72$ epigallokateşin, $\% 5.89$ epigallokateşin gallat, $\% 5.38$ kateşin gallat, $\% 4.04$ epikateşin gallat, \%2.83 gallokateşin, \%2.15 epikateşin ve $\% 1.37$ kateşinden oluştuğu görülmüştür.

Anahtar kelimeler: Siyah çay atı̆̆ı, çay kreması, konsantrasyon, bulanıklık, kateşin

\section{DETERMINATION OF CREAM FORMATION CONDITIONS AND ITS COMPOSITION DURING PRODUCTION OF CONCENTRATED TEA EXTRACT FROM BLACK TEA MANUFACTURING WASTES}

\footnotetext{
ABSTRACT

In this study, concentrated tea extract was obtained from Turkish black tea manufacturing wastes, the amount and composition of cream formed during production and also some properties of the concentrated product were determined. Accordingly, in order to determine the best extraction conditions, the treatments were carried out at three different temperatures $\left(75,85\right.$ and $\left.95{ }^{\circ} \mathrm{C}\right)$, five different time (15, 30, 45, 69 and 90 minutes) and two different waste tea/water feeding ratios (1/15

* Yazışmalardan sorumlu yazar / Corresponding author

(1): torun@akdeniz.edu.tr, (+90) 2423106520

县: (+90) 2423106306

Ferhan BalcI-Torun; ORCID no: 0000-0002-8972-1087

Kübra Sultan Özdemir; ORCID no: 0000-0002-7428-1840

Rukiye Mavuş; ORCID no: 0000-0002-6423-8561

Mehmet Torun; ORCID no: 0000-0002-6287-2993
} 
and 1/20). Extraction experiments showed that the best conditions were $95^{\circ} \mathrm{C}$ for 30 minutes in $1 / 15$ ratio and the water soluble dry matter content of the obtained extract was measured as $1.8^{\circ}$ $\mathrm{Bx}$, caffeine amount and turbidity value were $0.45 \mathrm{~g} / 100 \mathrm{~g}$ and $27.6 \mathrm{NTU}$, respectively. The highest amount $(1.98 \mathrm{~g} / 100 \mathrm{~mL})$ of tea cream formation was observed after 12 hours at $4{ }^{\circ} \mathrm{C}$ in the preconcentrated $\left(15^{\circ}-\mathrm{Bx}\right)$ extracts, the cream consisted of $15.88 \%$ caffeine, $17.08 \%$ protein, $8.72 \%$ epigallocatechin, $5.89 \%$ epigallocatechin gallate, $5.38 \%$ catechin gallate, $4.04 \%$ epicatechin gallate, $2.83 \%$ gallocatechin, $2.15 \%$ epicatechin and $1.37 \%$ catechin.

Keywords: Black tea waste, tea creaming, concentration, turbidity, catechin

\section{GİRİ̧̧}

Birçok bitkinin tohumu, çiçeği, dalları, yaprağ1, meyvesi, meyvesinin çekirdekleri veya kabukları değişik toplumlarda yüzyıllardır çay olarak tüketilmektedir. Bunlar içerisinde çay (Camellia sinensis) bitkisinin sürgün ve taze yapraklarından elde edilen çay ise kendine özgü tadı, aroması ve sağlığa faydalı özellikleri nedeniyle beş kıtaya yayllmış ve dünya genelinde sudan sonra en çok tüketilen alkolsüz içecek haline gelmiştir (Yılmaz vd., 2020). Çay yapraklarının farklı şekillerde işlenmesiyle siyah, yeşil ve oolong çay gibi farklı görünüss, tat ve lezzette çaylar elde edilebilmektedir. Bu çaylanı diğer bitki çaylarından farklı ve özel kılan en önemli maddeler ise bileşimlerinde bulunan kateşinler ve kafeindir (Balci ve Özdemir, 2016). Son yillarda gida bileşenlerinin antioksidan özelliklerinin ve gida sağlık ilişkilerinin belirlenmesi konusuna araşurmalar artmış ve bu araştırma sonuçlanı çayın önemli bileşenlerinden kateşinler ve bunların oksidasyon ürünü olan theaflavin (TF) ve thearubiginlerin (TR) sağllk üzerine olumlu etkilerinin olduğunu göstermiştir (Pou vd., 2019; Sen vd., 2020). Kendine has duyusal özellikleri yanında çayın insan sağlığı üzerine olan olumlu etkileri de çay tüketimini arttırmışır (de Mejia vd., 2009; Fatima ve Rizv, 2011). Bu durum, geleneksel çay tüketiminin dışında çaydan elde edilen yeni ürün arayısları ile çay katkılı ya da içeriğinde çay ekstrakt veya etken bileşenlerinin bulunduğu yeni ürünler geliştirme konusunda yapılan çalışmaları arttırmıştır. Nitekim, günümüzde farklı meyve aromalı soğuk çay, çay katkılı şekerlemeler, dondurmalar, kahvaltulık ve pastacılık ürünleri, gıda takviye edici çay ürünleri tüketicilerin hizmetine sunulmuştur. Bu konuda araşturmalar tüm dünyada devam etmektedir.

Soğuk çay üretiminde kullanılan çay ekstraktı, konsantre edilmiş ekstraktın $\left(>65^{\circ} \mathrm{Bx}\right)$ istenilen oranda seyreltilmesi ya da hızlı çözünür formda üretilen çayların tekrar çözündürülmesiyle sağlanmaktadır. Ancak soğuk çay üretimindeki en önemli problem; çay ekstraktı içerisindeki bazı bileşenlerin soğukta çözünürlüklerinin azalmasına bağlı olarak ekstraktta krema oluşumudur (Evans ve Bird, 2010). Çay ekstraktı çayın duyusal ve biyoaktif özelliklerinden sorumlu olan kateşinler ve kafein ile birlikte polisakkaritler, proteinler ve mineral maddelerin de bulunduğu kompleks bir yap1 içermektedir (Yin vd., 2009). Soğuk suda çözünmeyen maddeler "çay kreması" olarak nitelendirilmektedir. Çay kateşinleri ve siyah çayda kateşinlerin oksidasyon ürünleri (TF ve TR), kafein, protein, pektin ve metal iyonları ile etkileşime girdiğinde, çöken büyük kompleks yapılar (çay kreması) oluşmaktadır. Özellikle kateşinlerin gallatlanmış formlarının krema oluşumunda önemli bileşenler olduğu bildirilmektedir (Yin vd., 2009; Xu vd., 2012). Ekstrakt soğutulduğunda büyük boyuttaki bu oluşum gözle de görülebilir bir bulanıklık olarak algilanmakta ve soğuk çayda renk, parlaklık ve lezzet açısından tüketici beğenisini olumsuz yönde etkilemektedir. Ayrıca soğutulmuş çayda gözlenen çay kreması oluşumu çayın duyusal özelliklerinin yanı sıra ürünün sağlık üzerine olumlu etki gösteren potansiyelini de olumsuz yönde etkilemektedir (Dubey vd., 2020).

Çay kremasının çay ekstraktından ayrılması için farklı yöntemler uygulanabilmektedir. Çay kremasi santrifüj edilerek ekstrakttan ayrrlabileceği gibi farklı boyutlardaki membran filtrelerden geçirilerek de ayrilması sağlanabilmektedir (Argyle ve Bird, 2015). Soğutulmuş ekstraktın membran filtrelerden geçirilmesi ile bulanıklık çoğunlukla engellenebilmekte iken bu işlemin dezavantaj1 biyoaktif ve duyusal kaliteye etkili bileşenlerin konsantrasyonunu da azaltabilmesidir. Çay 
kremasının ayrılmasında fiziksel yöntemlerin yanı sıra kimyasal yöntemler de kullanılmaktadır. Gallatlanmış formdaki kateşinlerin hidrolize edilmesi için tannaz enziminin kullanılması gibi kimyasal yöntemler, elde edilecek ekstraktta burukluğa ve genel duyusal kalitesinde kayba neden olabilmektedir. Ayrıca enzim kullanımının üretim hattında kesikli çalışmayı gerektirmesi ve enzimin geri kazanılmasında yaşanan zorluklar da yöntemin diğer dezavantajları olarak görülmektedir. Düşük $\mathrm{pH}$ değerlerinde çay kreması oluşumunun azalmasına bağlı olarak esktrakta sitrik asit gibi asitliği arttırıcı maddelerin eklenmesi de çay ekstraktında duyusal açıdan olumsuzluklara neden olabilmektedir (Argyle ve Bird, 2015; Dubey vd., 2020).

Ülkemizde konsantre çay ekstraktı üretiminde siyah çay işlem atıklarının hammadde olarak kullanıldığ1 bilinmektedir. $\mathrm{Bu}$ bağlamda bu atıkların kullanılarak değerlendirilmesi ve ülke ekonomisine katma değer sağlaması oldukça önemli görülmektedir. Konsantre ekstrakt üretimi amaçlı kullanılan siyah çay atıklarını fabrikalarda oluşan; kurutma havası ile ayrılan lif ve tozlar, elektrostatik lif tutucuları tarafindan ayrılan atık, eleme artığ1 ve tasnif odasında oluşan üretim tozları oluşturmaktadır. Her $100 \mathrm{~kg}$ 'lık yaş çay, fabrikada işlendikten sonra yaklaşık $22-23 \mathrm{~kg}$ tasnif edilmemiş kuru çay elde edilmekte ve bu çayın yaklaşık \%13-15'i atık olarak ayrılmaktadır. Nitekim yaş çay hasat normuna, sürgün dönemine ve elde edilen siyah çayın kalitesine bağlı olarak siyah çay fabrikalarında randıman \%19-20 arasında değişmektedir. Büyük miktarlarda ortaya çıkan bu atık, üretime alınan taze çay yaprağının yaklaşık \%4'ünü oluşturmaktadır. Bu atıklarda selüloz oranı çok fazla olup çöp diye adlandırılmaktadır. Ancak bu atıkların piyasada satışa sunulan siyah çaylara kıyasla kateşin, TF ve TR içeriklerinin daha az olmasına bağlı olarak daha düşük miktarda ekstrakt verimi, zayıf duyusal ve fonksiyonel özellikleri söz konusudur. Siyah çay üretim atklarını değerlendirmek amaçı çalışmalar ve uygulamalar bulunmakla beraber bu atıklardan konsantre çay ekstraktı üretimi son zamanlarda katma değerli bir üretim olarak dikkat çekmektedir. Böylece geriye kalan organik madde hala gübre, yakıt vb şekillerde kullanılmaya uygun olabilmektedir. Halihazırda konsantre çay üretim hattı genel olarak ekstraksiyon, süzme, kaba partiküllerin ayrımı için seperasyon, ön konsantrasyon, soğutma ve son konsantrasyon aşamalarından oluşmaktadır, (Özdemir, 1992; Özdemir Vd., 2018).

Yapılan bu çalışmada siyah çay işlem atıklarından elde edilecek çay konsantresinin üretim aşamalarında çay ekstraktının bileşimi ve değişiminin belirlenmesi amaçlanmıştır. $\mathrm{Bu}$ doğrultuda piyasadan temin edilen çay atıkları kullanılarak çay konsantresi üretilmiş ve bu işlem süresince hem çay ekstraktlarında hem de oluşan kremada bazı bileşim analizleri gerçekleştirilmiştir. Literatürde farklı ülkelerin siyah ve yeşil çay esktraktlarında krema oluşumu ve oluşan kremanın bileşimine yönelik çalışmalar mevcut olsa da Türk çayında ve atıklarında krema oluşumu ve bileşimi ile ilgili bir çalışmaya rastlanılamamıştır. $\mathrm{Bu}$ bakımdan çalışma literatürde ilk olma özelliği taşımaktadır.

\section{MATERYAL VE YÖNTEM Materyal}

Çalışma kapsamında kullanılan çay atıkları Doğu Karadeniz Bölgesi'nde siyah çay üretimi yapan bir fabrikadan temin edilmiştir. Kullanılan atıklar siyah çay üretim hattının 2 farklı noktasından (elektrostatik lif tutucularında tutulan ve tasnif odasından) alınmış ve çalışmalar öncesi bu atıklar 1:1 oranında karıştırılarak çalışmalarda kullanılmıştır. Analizlerde kullanılan kimyasallar Merck (Darmstat, Almanya) firmasindan temin edilmiştir.

\section{Ekstraksiyon}

Siyah çay atığ örneklerinden en uygun ekstraksiyon koşullarının belirlenmesi amacıyla ekstraksiyon çalışmaları üç farklı sıcaklık $(75,85$ ve $\left.95^{\circ} \mathrm{C}\right), 5$ farklı süre $(15,30,45,69$ ve 90 dakika) ve 2 farklı atık çay/su besleme oranında (1/15 ve $1 / 20$ ) çalkalamalı su banyosunda (Daihan WSB30) $150 \mathrm{rpm}$ karıştırma hızında gerçekleştirilmiştir. Bu amaçla 250mL'lik ağz1 sızdırmaz cam balonlara çay atığ1 örnekleri tartılarak üzerine $100 \mathrm{~mL}$ saf su eklenmiş, eklenilen saf su sıcaklıkları termometre ile ölçülüp istenilen ekstraksiyon sıcaklığına ulaşıp ulaşmadığı kontrol edilmiştir. Ekstraksiyon işleminden sonra 
su banyosundan çıkartılıp hızla soğutulan örnekler önce kaba filtre kağıdından (gözenek çapı 2-4 $\mu \mathrm{m}$ ) süzülmüş, daha sonra da 15000 g'de 15 dakika santrifüj edilerek analizler için kullanıma hazır hale getirilmiştir. Ekstraksiyon aşamasının en uygun şartlarının belirlenmesinde ekstraktların briks değeri $\left({ }^{\circ} \mathrm{Bx}\right)$ ve kafein miktarı cevap olarak kullanılmıştır.

\section{Ekstraktların ön konsantrasyonu}

En uygun koşullarda elde edilen ekstraktlar krema ayrımı öncesi ön konsantrasyon amaciyla döner buharlaştırıcı (Laborota 4000, Heidolph) yardımı ile $60{ }^{\circ} \mathrm{C}$ sicaklikta $15{ }^{\circ} \mathrm{Bx}$ değerine kadar konsantre edilmiştir.

Ekstraktlarda krema oluşumunun izlenmesi ve oluşan kremanın ayrılması

Ön konsantre çay atığ1 ekstraktlarında krema oluşumunun sağlanabilmesi için $15^{\circ} \mathrm{Bx}$ 'e getirilen ekstrakt $4{ }^{\circ} \mathrm{C}^{\prime}$ de farklı sürelerde $(3,6,9,12$, 18 ve 24 saat) bekletilmiştir. Belirtilen sürelerde ekstraktlarda oluşan kremanın ayrılabilmesi için 4 ${ }^{\circ} C^{\prime}$ de $15000 g$ g'de santrifüj işlemi uygulanmıştur.

\section{Konsantre çay ekstraktının eldesi}

$65{ }^{\circ}$ Bx'lik konsantre çay attğını elde etmek amacıyla kreması ayrılmış $15{ }^{\circ}$ Bx'lik çay ekstraktları döner buharlaştırıcı (Laborota 4000, Heidolph) yardımı ile $60{ }^{\circ} \mathrm{C}$ sicaklıkta konsantre edilmiştir. Siyah çay atı̆̆ından konsantre ekstrakt üretimi amaçlı bu aşamaya kadar yapılan ve yukarıda anlatılan tüm işlemler Şekil 1'de gösterilmiştir.

\section{Kuru madde tayini}

Elde edilen ekstraktların ve ayrilan kremanın kuru madde miktarı hızlı nem tayini cihazı ile (Kern, DBS-60, Almanya) belirlenmiştir.

\section{Suda Çözünür Kuru Madde Analizi}

Ekstraktların suda çözünür kurumadde değerleri dijital refraktometre (Hanna Digital H10, ABD) kullanılarak ölçülmüsstür. Ölçümler $25 \pm 1^{\circ} \mathrm{C}$ 'de gerçekleştirilmiştir.

\section{Krema miktarının belirlenmesi}

Çay ekstraktlarında oluşan çay kremasının belirlenmesi Yin vd. (2009)'a göre gerçekleştirilmiştir. $\mathrm{Bu}$ amaçla elde edilen çay ekstraktları $10000 \quad$ g'de 15 dakika santrifüj edilmisstir. Üst faz ayrrldıktan sonra altta kalan kısım 2 aşamada toplamda $10 \mathrm{~mL}$ saf su ile alınarak darası alınmış petriye aktarılmış ve 80 ${ }^{\circ} \mathrm{C}$ 'de 48 saat etüvde bekletildikten sonra ağırlık farkından krema miktarı hesaplanmıştır.

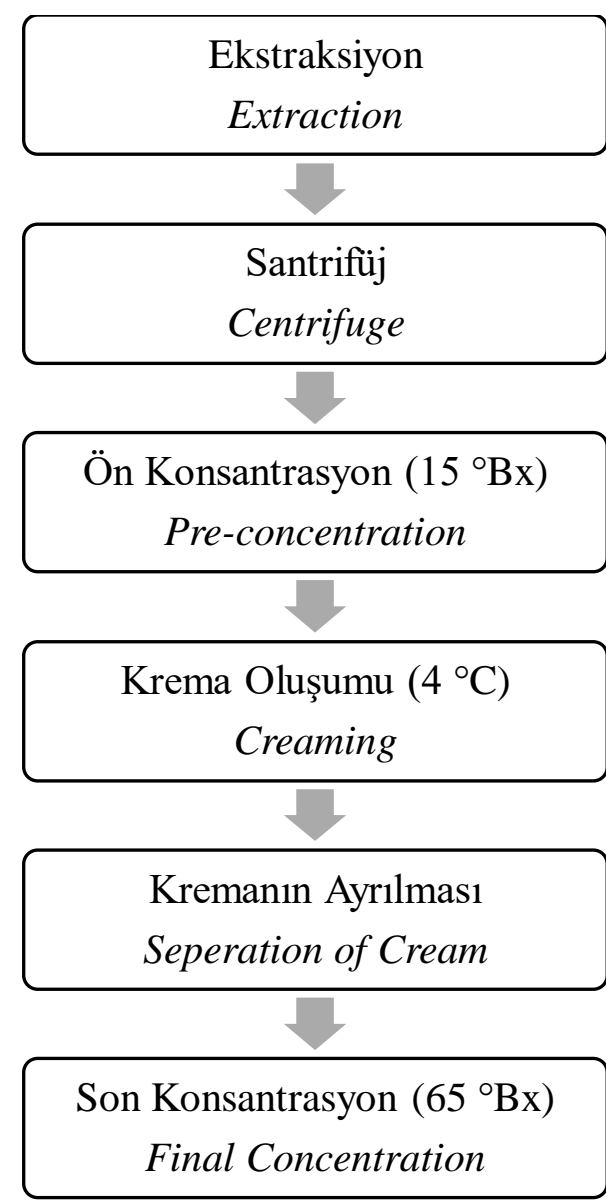

Şekil 1. Konsantre Çay Atığı Üretim Akım Şemas1

Figure1. The Flow Chart of Concentrated Tea Waste Production

\section{Geri kazanım}

Ekstraksiyon işleminde kullanılan suyun laboratuvar şartlannda kendiliğinden gerçekleştirilen süzme işleminde ne kadarlık kısmının çay posasından geri alınabildiğinin saptanması amaciyla kazanım oranı belirlenmiştir. $\mathrm{Bu}$ amaçla ekstraksiyonda kullanilan suyun ekstraksiyon sonucunda elde edilen ekstraksiyon miktarına oranı geri kazanım değeri (\%) olarak ifade edilmiştir. 


\section{Bulanıklık tayini}

Örneklerin bulanıklık değeri ölçümü için türbidimetre (Hach $2100 \mathrm{~N}$ Turbidimeter, A.B.D.) kullanılmış olup, bulanıklık değerleri NTU (Nepholometric Turbidity Unit) değeri cinsinden ifade edilmiştir (Tajchakavit vd., 2001).

\section{HPLC ile kafein ve kateşin profili analizi}

Ekstraktların kateşin ve kafein analizleri Wang ve Helliwell (2000)'e göre kısmen modifiye edilerek gerçekleştirilmiştir. $\mathrm{Bu}$ amaç doğrultusunda çay atığ1 örnekleri ve ayrilan krema gerekli seyreltmeleri yaptıktan sonra $0.45 \mu m^{\prime} l i k$ membran filtreden süzülüp, HPLC (ShimadzuUV 160A)'ye enjekte edilmiştir. Bileşenlerin ayrıminda Inertsil ODS $3(250 \times 4.6 \mathrm{~mm}, 5 \mu \mathrm{m}$, GL Sciences, Japan) kolon kullanılmıştır. Analizde mobil faz olarak \% 0.1 ortafosforik asit içeren su (A fazı) ve $\% 0.1$ ortafosforik asit içeren metanol (B fazı) kullanılmıştır. Mobil faz akış hızı 1 $\mathrm{mL} /$ dakika olup, akış programı $0-5$ dakika arası $\%$ 20 B fazı, 5-7 dakika arası \% 20-24 B fazı, 7-10 dakika arası \% 24 B fazı, 10-20 dakika arası \% 2440 B fazı ve son $20-40$ dakika arası $\% 50$ B fazı olarak ayarlanmıştır. Analiz süresince kolon sıcaklığ $30{ }^{\circ} \mathrm{C}$ olup bileşenlerin tanımlanması 280 nm'de yapılmıştır. Araşturma kapsamında örneklerdeki kafein ve kateşin konsantrasyonunun belirlenebilmesi için örneklerin yürütüldüğgu koşullarda standartlar önce farklı konsantrasyonlarda tek olarak, daha sonra da karma halde yine farklı konsantrasyonlarda yürütülmüş ve tutulma zamanları belirlenmiştir.

\section{TF-TR analizi}

Çay esktraktlarının TF ve TR değerleri Gürses ve Artık (1987)'e göre yapılmıştır. Bu amaçla elde edilen çay atı̆̆1 ekstraktlardan $10 \mathrm{~mL}$ alınmış ve üzerine $10 \mathrm{~mL} \% 1$ 'lik disodyum hidrojenfosfat eklenip karıştırılmıştır. Karışım $10 \mathrm{~mL}$ etil asetat ile ekstrakte edilerek ardından etil asetat tabakasından $2 \mathrm{~mL}$ alınıp metanol ile $25 \mathrm{~mL}$ 'ye seyreltilmiştir (E1). Diğer taraftan $1 \mathrm{~mL}$ çay atı̆̆ 1 ekstraktına $9 \mathrm{~mL}$ distile su karıştırlıp metanol ile 25 mL'ye tamamlanmıştır (E2). Ayrıca $1 \mathrm{~mL} \%$ 10'luk okzalik asit çözeltisine $1 \mathrm{~mL}$ çay atı̆̆ ekstraktı ve $8 \mathrm{~mL}$ distile su ilave edilip metil alkol ile 25 mL'ye seyreltilmiştir (E3). Elde edilen ekstraktlar spektrofotometrede $380 \quad$ nm'de okunmuş ve bu değerler aşağıdaki formüllerde yerlerine konularak TF ve TR değerleri hesaplanmıştır.

$\mathrm{TF}(\%)=2.25 \times 2 \mathrm{E} 1$

$\mathrm{TR}(\%)=7.06 \times(4 \mathrm{E} 3-2 \mathrm{E} 1)$

\section{İstatistiksel analiz}

Siyah çay atıklarından ekstraksiyon, krema ayrımı ve konsantrasyon işlemleri iki tekerrürlü olarak yapılmış, analizler üç paralelli olarak gerçekleştirilmiştir. Analiz sonucunda elde edilen verilere varyans analizi ve önemli bulunan faktörlere ise Duncan Çoklu Karşılaştırma Testi uygulanmıştrr. Tüm istatistiki hesaplamalar SAS programı (SAS, Cary, NC, USA) ile gerçekleştirilmiş olup değerler ortalama \pm standart hata şeklinde verilmiştir.

\section{BULGULAR VE TARTIŞMA}

\section{Ekstraksiyon şartlarının bileşime etkisi}

Siyah çay konsantresi üretiminde ilk aşama ekstraksiyon olup, kat1-siv1 ekstraksiyonunda katıdan suya geçebilecek maddelerin en yüksek oranda alınabilmesi sonraki aşamalar için işlem süresi ve ekonomisi açısından önem arz etmektedir. Katıdan sıviya kütle transferinde materyalin partikül boyutu, ekstraksiyon sıcaklığ1, süresi ve kullanılan materyal/su oranı etkili faktörler olduğu için çalışma kapsamında ekstraksiyon sicaklığı, süresi ve kullanılan çay/su oranının etkisi araştırılmıştır. En uygun ekstraksiyon şartlarındaki hedef; çay ekstraktında en yüksek ${ }^{\circ} \mathrm{Bx}$ değerinin ve kafein miktarının sağlanması olmuştur. Ekstrakttaki kuru madde miktarının yüksek olması bundan sonraki konsantrasyon işlemi sırasında enerji maliyetin azalmasına neden olabileceği gibi aynı zamanda evaporasyon süresi azalacağından dolayı üründe 1 sıl işlemler nedeniyle oluşabilecek kontaminantlar da azaltılmış olacaktır. En uygun ekstraksiyon sicaklığının belirlenmesinde hedef bileşen olarak kafeinin seçilmesinin nedeni ise ÇAYKUR tarafından belirtilen soğuk çay ekstraktının taşıması gereken özelliklerinde kimyasal bileşen olarak kafein alt limitinin (son üründe en az 2.5 $\mathrm{g} / 100 \mathrm{~g}$ kuru madde) yer almasıdır. Bu hedefler doğrultusunda öncelikle test edilen 3 farklı ekstraksiyon sicaklığından $\left(75^{\circ} \mathrm{C}, 85^{\circ} \mathrm{C}\right.$ ve $\left.95^{\circ} \mathrm{C}\right)$ 
en uygun sicaklik belirlenmiştir. En uygun sicaklığın belirlendiği denemelerde besleme oranı (1:15, çay atı̆̆1:su) ve ekstraksiyon süresi (30 dakika) sabit tutulmuştur.

Çizelge 1'de 3 farklı sıcaklıkta elde edilen çay atığı ekstraktlarının ${ }^{\circ} \mathrm{Bx}$, kafein miktarı (g/100 g KM) ve ekstraksiyon sonucunda kazanilan ekstraktn miktarına (\%) ilișkin sonuçlar verilmiștir. Çizelge incelendiğinde ekstraktların ${ }^{\circ} \mathrm{Bx}$ ve kafein miktarı değerlerinin ekstraksiyon sicaklığ1 ile arttığ1, bu artışı ${ }^{\circ} \mathrm{Bx}$ değerlerinde istatistiki açıdan önemli $(P$ $<0.05)$ olduğu görülmektedir. En yüksek ${ }^{\circ} \mathrm{Bx}$ değeri (1.80) ve kafein miktarı (0.45 g/100 g KM) $95{ }^{\circ} \mathrm{C}$ sicaklikta yapilan ekstraksiyon sonucunda belirlenmiştir. Çizelge 1'de verilen ekstraksiyon sonrası çay atı̆̆ından geri kazanılan ekstrakt miktarlarına ait sonuçlar incelendiğinde ekstraksiyon sonrasi sivinin ekstraksiyon sıcaklığına bağlı olarak \% 65.65-67.97 arasında geri alınabildiği, ekstraksiyon sıcaklığının değerler üzerinde etkisinin önemli olmadığ1 $(P>0.05)$ görülmektedir. Balci ve Özdemir (2016), yeşil çay için $85^{\circ} \mathrm{C}$ ekstraksiyon sıcaklığının kritik bir değer olduğunu, bu sıcaklığa kadar suya madde miktar1 geçişinin arttığı, bu sıcaklıktan sonra ise artış hızının azaldığı ve hemen hemen dengeye geldiğini belirtmişlerdir. Elde edilen ekstraktun ${ }^{\circ} \mathrm{Bx}$ ve kafein madde miktarı değerleri $95{ }^{\circ} \mathrm{C}$ sıcaklıkta elde edildiği için en uygun besleme oranı ve ekstraksiyon süresi çalışmaları bu sıcaklıkta yürütülmüştür. Ekstraksiyonda kullanılan katı materyalin oranının azalmasıyla ekstraktın ${ }^{\circ} \mathrm{Bx}$ miktarı değerinin ve ekstrakta bulunan kafein miktarının istatistiki açıdan önemli derecede $(P<$ 0.05) azaldığı tespit edilmiştir (Çizelge 1). Kat1-sıv1 ekstraksiyonlarında konsantrasyon farkı arttıkça ekstraksiyon hızının arttığ1, ancak çözgene geçebilecek maddelerin denge konsantrasyonuna ulaştı̆̆ noktada ne kadar fazla katı madde beslenirse ${ }^{\circ} \mathrm{Bx}$ değerinin de $\mathrm{o}$ oranda artış gösterdiği bildirilmiştir (Torun vd., 2015). Elde edilen sonuçlar doğrultusunda çay atığı:su oranında en uygun oranın 1:15 olduğu belirlenmiştir. Süreye bağlı sonuçlar değerlendirildiğinde ise ekstraktların ${ }^{\circ} \mathrm{Bx}$ ve kafein içerikleri istatistiki açıdan önemli $(P<0.05)$ bir değişim göstermiştir. Ekstraktların ${ }^{\circ} \mathrm{Bx}$ ve kafein değerleri 15 dakikalık süre sonunda sırasıyla 1.30 ve $0.40 \mathrm{~g} / 100 \mathrm{~g} \mathrm{KM}$ olarak belirlenirken, 90 dakikalık süre sonunda bu değerler sirasıyla 2.00 ve $0.45 \mathrm{~g} / 100 \mathrm{~g} \mathrm{KM}$ olarak belirlenmiştir. Ekstraktların ${ }^{\circ} \mathrm{Bx}$ ve kafein değerlerindeki istatistiksel açıdan önemli değişim 30. dakika itibariyle oluşmuş ve bu sürelerden sonraki değişim istatistiki açıdan önemli bulunmamıştır $(P$ $>0.05)$.

Çizelge 1. Farklı sıcaklık, süre ve besleme oranlarında yapılan ekstraksiyon sonucu elde edilen ekstraktların özellikleri

Table 1. Properties of extracts obtained as a result of extraction at different temperatures, times and ratios

\begin{tabular}{|c|c|c|c|c|c|}
\hline $\begin{array}{l}\text { Sicaklik }\left({ }^{\circ} \mathrm{C}\right) \\
\text { Temperature } \\
\left({ }^{\circ} \mathrm{C}\right)\end{array}$ & $\begin{array}{l}\text { Süre (Dakika) } \\
\text { Time (Minute) }\end{array}$ & $\begin{array}{l}\text { Kat1/Siv1 } \\
\text { oran1 } \\
\text { Solid/Liquid } \\
\text { ratio }\end{array}$ & $\begin{array}{l}\mathrm{SCSKM}\left({ }^{\circ} \mathrm{Bx}\right) \\
W S D M\left({ }^{\circ} \mathrm{B} x\right)\end{array}$ & $\begin{array}{c}\text { Kafein Miktarn (g/100 } \\
\text { g KM) Caffeine content } \\
(g / 100 g \text { DM) }\end{array}$ & $\begin{array}{c}\text { S1v1 kazanımı (\%) } \\
\text { Liquid gain }(\%)\end{array}$ \\
\hline 75 & \multirow{3}{*}{30} & \multirow{3}{*}{$1 / 15$} & $1.40 \pm 0.07^{\mathrm{c}}$ & $0.41 \pm 0.03$ & $65.65 \pm 1.13$ \\
\hline 85 & & & $1.60 \pm 0.06^{\mathrm{b}}$ & $0.43 \pm 0.00$ & $67.37 \pm 1.74$ \\
\hline 95 & & & $1.80 \pm 0.08^{\mathrm{a}}$ & $0.45 \pm 0.07$ & $67.97 \pm 0.74$ \\
\hline \multirow{2}{*}{95} & \multirow{2}{*}{30} & $1 / 15$ & $1.80 \pm 0.05^{\mathrm{a}}$ & $0.44 \pm 0.02^{\mathrm{a}}$ & $68.03 \pm 0.95$ \\
\hline & & $1 / 20$ & $1.20 \pm 0.04^{b}$ & $0.27 \pm 0.00^{\mathrm{b}}$ & $68.28 \pm 2.57$ \\
\hline \multirow{6}{*}{95} & 15 & \multirow{6}{*}{$1 / 15$} & $1.30 \pm 0.04^{b}$ & $0.40 \pm 0.04^{b}$ & $67.53 \pm 1.74 \mathrm{c}$ \\
\hline & 30 & & $1.80 \pm 0.05^{\mathrm{b}}$ & $0.46 \pm 0.05^{\mathrm{a}}$ & $67.97 \pm 1.38^{\mathrm{c}}$ \\
\hline & 45 & & $1.90 \pm 0.07 \mathrm{ab}$ & $0.47 \pm 0.00^{\mathrm{a}}$ & $70.65 \pm 3.57 \mathrm{bc}$ \\
\hline & 60 & & $1.90 \pm 0.06^{\mathrm{ab}}$ & $0.48 \pm 0.02^{\mathrm{a}}$ & $75.17 \pm 3.90^{\mathrm{ab}}$ \\
\hline & 75 & & $2.00 \pm 0.07 \mathrm{a}$ & $0.46 \pm 0.01^{\mathrm{a}}$ & $76.88 \pm 2.48^{a}$ \\
\hline & 90 & & $2.00 \pm 0.04^{a}$ & $0.45 \pm 0.03^{\mathrm{a}}$ & $76.56 \pm 2.58^{\mathrm{a}}$ \\
\hline
\end{tabular}

Sonuçlar Ortalama \pm Standart Hata olarak verilmiştir. Aynı sütundaki farklı harfler istatistiksel farkı ifade etmektedir $(P<0.05)$. SÇKM: Suda Çözünür Kuru Madde

$V$ alues are given as Mean \pm Standard Error. Different letters in same column mean the statistical significance $(P<0.05)$. WSDM: Water Soluble Dry Matter 
En uygun olarak belirlenen koşullarda $\left(95^{\circ} \mathrm{C}, 45\right.$ dakika, 1:15 attk çay:su oranı) yapılan ekstraksiyon sonucunda elde edilen ekstraktn bazı kalite özelliklerine ilişkin sonuçlar Çizelge 2'de, kateşin kompozisyonuna ait sonuçlar ise Çizelge 3'de verilmiştir. Çizelge 2 incelendiğinde çay atıkları ile elde edilen ekstraktın ${ }^{\circ} \mathrm{Bx}$ değerinin 1.8 , kafein miktarının $0.45 \mathrm{~g} / 100 \mathrm{~g}$ KM ve bulanıklik değerinin 27.6 NTU olduğu görülmektedir. Çay atığının bileşimi üzerine yapılmış olan bir çalışmada çay atığındaki kafein oranı $0.14-0.18$ g/100 g (Gürü ve İçen, 2004), İran'da üretilen siyah çay attğının bileşimini araştırıldığı çalışmada (Shalmashi vd., 2010) ise kafein miktarı 0.77 $\mathrm{g} / 100 \mathrm{~g}$ olarak rapor edilmiştir. Çalışmada elde edilen kafein miktarı rapor edilen sonuçlarla kısmen benzerlik göstermekte olup, aradaki farklılıkların materyalin sürgün dönemi, işlenme şekli, bekleme süresi ve ekstraksiyon şartlarından kaynaklanabileceğini söylemek mümkündür. Siyah çaydaki kafein miktarı çay yaprağının varyetesi, bakım budama ve gübreleme gibi kültürel tedbirler, toplama standard1, sürgün dönemi, ekstraksiyon koşullarına bağlı olarak \% 25 arasında değişmektedir (Zhu vd., 2019). Kafein bir yeşil çay sürgününde en yüksek yaprak tomurcuğu ve takip eden 1 . ve 2. taze yapraklarda bulunmakta olup, yaşlı yapraklarda, yaprak sapı ve sürgün gövdesinde miktarı azalmaktadır. Kaliteli bir siyah çay üretimi çay terminolojisinde 2.5 yaprak (tomurcuk +2 takip eden iki yaprak) olarak bilinen kısımdan üretilmekte olup, materyalde kart yaprak ve sap oranı arttıkça kalite düşmektedir. Nitekim bu çalışmada kullanılan çay atığı da açıklandığ1 üzere sap ve kart yapraklardan oluştuğu için örneğin kafein miktarı satışa sunulan siyah çaylara göre daha düşük bulunmuştur.

Çizelge 2. Çay atığı ekstraktlarının bazı kalite özellikleri

Table 2. Some quality properties of tea waste extracts

\begin{tabular}{lccccc}
\hline & $\begin{array}{c}\text { SCKKM } \\
\left({ }^{\circ} \mathrm{Bx}\right) \\
\text { WSDM } \\
\left({ }^{\circ} \mathrm{B} x\right)\end{array}$ & $\begin{array}{c}\text { Kafein miktar1 } \\
(\mathrm{g} / 100 \mathrm{~g} \mathrm{KM}) \\
\text { Caffeine content } \\
(\mathrm{g} / 100 \mathrm{~g} D \mathrm{D})\end{array}$ & $\begin{array}{c}\text { Bulaniklik } \\
(\mathrm{NTU}) \\
\text { Turbidity } \\
(\mathrm{NTU})\end{array}$ & $\begin{array}{c}\text { TF }(\%) \\
\text { TF } \%)\end{array}$ & $\begin{array}{c}\text { TR }(\%) \\
\text { TR }(\%)\end{array}$ \\
\hline $\begin{array}{l}\text { Ekstrakt } \\
\text { Extract }\end{array}$ & $1.80 \pm 0.01^{\mathrm{c}}$ & $0.45 \pm 0.02^{\mathrm{c}}$ & $27.60 \pm 2.48^{\mathrm{a}}$ & $0.33 \pm 0.06$ & $23.22 \pm 2.42$ \\
\hline $\begin{array}{l}\text { Ön konsantre ekstrakt } \\
\text { Pre-concentrated extract }\end{array}$ & $15.00 \pm 0.94^{\mathrm{b}}$ & $3.37 \pm 0.07 \mathrm{~b}$ & $34.00 \pm 4.76^{\mathrm{a}}$ & $0.24 \pm 0.10$ & $19.50 \pm 2.08$ \\
\hline $\begin{array}{l}\text { Konsantre ekstrakt } \\
\text { Concentrated extract }\end{array}$ & $65.00 \pm 1.43^{\mathrm{a}}$ & $20.77 \pm 1.76^{\mathrm{a}}$ & $3.93 \pm 0.59^{\mathrm{b}}$ & $0.21 \pm 0.05$ & $18.01 \pm 1.67$ \\
\hline
\end{tabular}

Sonuçlar Ortalama \pm Standart Hata olarak verilmiştir. Aynı sütundaki farklı harfler istatistiksel farkı ifade etmektedir $(P<0.05)$. SÇKM: Suda Çözünür Kuru Madde

$V$ alues are given as Mean \pm Standard Error. Different letters in same column mean the statistical significance $(P<0.05)$. WSDM: Water Soluble Dry Matter

En uygun şartlarda elde edilen ekstraktların ön konsantrasyonu

Kaba filtre kağıdında yapılan süzme işlemi ardından daha küçük partiküllerin de santrifüj seperasyonla ayrilması sonrasında $1.8{ }^{\circ}$ Bx'lik çay atığ1 ekstraktt rotary evaporatörde $15^{\circ} \mathrm{Bx}$ 'e kadar konsantre edilmiştir. Briks değeri 1.8 olan 250 mL'lik çay esktraktı $60{ }^{\circ} \mathrm{C}$ 'de 2 saat süre sonunda $15{ }^{\circ}$ Bx'e getirilmiştir. Yapılan konsantrasyon işlemi sonrasında elde edilen $15^{\circ} \mathrm{Bx}$ 'lik çay atığ 1 ekstraktının bazı kalite özelliklerine ilişkin sonuçlar Çizelge 2'de, kateşin kompozisyonuna ait sonuçlar ise Çizelge 3'de verilmiştir. Çizelge 2 incelendiğinde ön konsantre ekstraktın bulanıklık değerinin istatistiki açıdan önemsiz olmakla birlikte 27.60 NTU'dan 34.00 NTU'ya arttğ1 görülmekte olup bu durum bulanıklık unsuru oluşturan bileşenlerin konsantre olması ile ilişkilendirilmiştir. Çizelge 2'de verilen TF ve TR değerleri ise çay yaprağında bulunan kateşinlerin siyah çay üretimindeki oksidasyon aşamasında yükseltgenmesiyle oluşan bileşikler olup bu bileşenler siyah çayın içim özelliklerinden (dolgunluk, burukluk, renk ve parlaklık) sorumludurlar. Kaliteli bir siyah çayda TF/TR oranının 1/10-1/12 arasında olması gerektiği 
bilinmektedir. Sonuçlar incelendiğinde çay atı̆̆ ekstraktının TF ve TR değerlerinin konsantrasyona bağlı önemli derecede $(P>0.05)$ değişmediği görülmüştür.

Çizelge 3. Çay atı̆̆1 ekstraktlarının ve oluşan kremanın kateşin kompozisyonu (g/100 g KM)

\begin{tabular}{|c|c|c|c|c|c|c|c|c|}
\hline & EGCG & GA & $\mathrm{C}$ & EGC & $\mathrm{EC}$ & GC & ECG & CG \\
\hline $\begin{array}{l}\text { Ekstrakt } \\
\text { Extract }\end{array}$ & $0.16 \pm 0.01^{\mathrm{d}}$ & $0.07 \pm 0.00^{\mathrm{d}}$ & $0.08 \pm 0.00^{\mathrm{d}}$ & $0.12 \pm 0.01^{\mathrm{d}}$ & $0.41 \pm 0.04^{\mathrm{d}}$ & $0.06 \pm 0.01^{\mathrm{b}}$ & $0.07 \pm 0.00^{\mathrm{b}}$ & $0.06 \pm 0.03^{c}$ \\
\hline $\begin{array}{l}\text { Ön } \\
\text { konsantre } \\
\text { ekstrakt } \\
\text { Pre- } \\
\text { concentrated } \\
\text { extract }\end{array}$ & $0.59 \pm 0.02^{\mathrm{c}}$ & $0.45 \pm 0.01^{\mathrm{c}}$ & $2.06 \pm 0.07^{\mathrm{b}}$ & $0.39 \pm 0.01^{\mathrm{c}}$ & $6.93 \pm 0.01^{\mathrm{b}}$ & $0.86 \pm 0.02^{\mathrm{b}}$ & $0.90 \pm 0.00^{\mathrm{b}}$ & $1.14 \pm 0.03^{c}$ \\
\hline $\begin{array}{l}\text { Konsantre } \\
\text { ekstrakt } \\
\text { Concentrated } \\
\text { extract }\end{array}$ & $5.89 \pm 0.37 \mathrm{a}$ & $0.60 \pm 0.15^{\mathrm{b}}$ & $1.37 \pm 0.17 \mathrm{c}$ & $8.72 \pm 1.83^{b}$ & $2.15 \pm 0.55^{c}$ & $2.83 \pm 0.18^{a}$ & $4.04 \pm 0.25^{\mathrm{a}}$ & $5.38 \pm 0.15^{\mathrm{a}}$ \\
\hline $\begin{array}{l}\text { Krema } \\
\text { Cream }\end{array}$ & $4.97 \pm 0.17 \mathrm{~b}$ & $0.75 \pm 0.09^{a}$ & $3.60 \pm 0.47 \mathrm{a}$ & $5.88 \pm 0.99 \mathrm{a}$ & $14.21 \pm 1.54^{a}$ & $2.69 \pm 0.13^{a}$ & $2.82 \pm 0.11^{\mathrm{a}}$ & $3.64 \pm 0.16^{\mathrm{b}}$ \\
\hline
\end{tabular}

Sonuçlar Ortalama \pm Standart Hata olarak verilmiștir. Aynı sütundaki farklı harfler istatistiksel farkı ifade etmektedir $(P<0.05)$. EGCG: Epigallokateşin gallat, GA: Gallik asit, C: Kateşin, EGC: Epigallokateşin, EC: Epikateşin, GC: Gallokateşin, ECG: Epikateşin gallat, CG: Kateşin gallat

Values are given as Mean土Standard Error. Different letters in same column mean the statistical significance $(P<0.05)$. EGCG: Epigallocatechin gallate, GA: Gallic acid, C: Catechin, EGC: Epigallocatechin, EC: Epicatechin, GC: Gallocatechin, ECG: Epicatechin gallate, CG: Catechin gallate.

Çizelge 3'de verilen ekstraktların kateşin kompozisyonuna ilișkin veriler incelendiğinde bașlangic ekstraktlarında en fazla epikateșin $(0.41$ $\mathrm{g} / 100 \mathrm{~g} \mathrm{KM})$, epigallokateşin gallat $(0.16 \mathrm{~g} / 100 \mathrm{~g}$ $\mathrm{KM})$ ve epigallokateşin $(0.12 \mathrm{~g} / 100 \mathrm{~g} \mathrm{KM})$ tespit edilmiştir. Ön konsantre edilen ekstraktlarda ise en fazla sirasiyla epikateşin (6.93 g/100 g KM), kateşin $(2.06 \mathrm{~g} / 100 \mathrm{~g} \mathrm{KM})$ ve kateşin gallat $(1.14$ $\mathrm{g} / 100 \quad \mathrm{~g} \quad \mathrm{KM})$ belirlenmiştir. Ekstraktların konsantre edilmesi ile beklendiği gibi tüm kateşinlerin miktarı artmış, ancak epigallokateşin gallat gibi bazı kateşinlerin artışının kuru madde artışına bağlı oransal olarak gerçekleşmediği görülmüş, bu durumun kateşinlerin isısal hassasiyetlerinin farklı olmasindan ve is1 uygulaması ile epimerizasyona uğramış olmalarından kaynaklanmış olabileceği düşünülmektedir. Nitekim çay kateşinlerinin sıcaklıkla birlikte epimerizasyona uğradığ1 bildirilmiștir (Balc1 ve Özdemir, 2016)

\section{Çay ekstraktının bekletilme süresinin krema oluşumuna etkisi}

Ön konsantre edilen örneklerin zamana bağl1 krema oluşumunun belirlenmesi amaciyla örnekler $4{ }^{\circ} \mathrm{C}$ 'de farklı sürelerde $(3,6,9,12$, 18 ve 24 saat) bekletilerek, bekletme sürelerinin sonunda ekstraktta oluşan krema santrifüj ile ayrılmış (Şekil 2) ve miktarları Çizelge 4'de, kremanın kafein, protein, TF ve TR değerleri ise Çizelge 5'de verilmiştir. Ayrıca kremanın kateşin kompozisyonu da belirlenerek Çizelge 3'de sunulmuştur.

Çizelge 4 incelendiğinde ekstrakttan ayrllan krema miktarının zamana bağlı olarak istatistiksel açıdan farklılık ( $P<0.05)$ gösterdiği, 12 saate kadar artarak 12 saat sonunda en yüksek miktara $(1.98 / 100 \mathrm{~mL})$ ulaştı̆̆1 görülmektedir.

Oluşan 1.98 g miktarındaki krema çay atığından elde edilen ve $15^{\circ}$ Bx'e konsantre edilen $100 \mathrm{~mL}$ ekstraktın kuru maddesinin yaklaşık \%13'ünü oluşturduğu göz önüne alındığında çayın önemli bir kısmının krema ile uzaklaştırıldığı söylenebilir. Nitekim Cizelge 5'de verilen sonuçlar incelendiğinde kremanın $15.88 \mathrm{~g} / 100 \mathrm{~g} \mathrm{KM}$ oranında kafein ve $17.08 \mathrm{~g} / 100 \mathrm{~g}$ KM oranında protein içerdiği görülmektedir. $\mathrm{Bu}$ çalışma kapsamında analiz edilmese de kremayı oluşturan diğer önemli bileşenlerin karbonhidratlar ve minerallerden oluştuğu bilinmektedir. Lin vd. (2015) tarafından siyah ve yeşil çay ekstraktlarında oluşan kremanın bileşiminin belirlendiği çalışma 
sonucunda siyah çay ekstraktından ayrilan kremanın bileşiminin \%24 TR, \%23 protein, \%18 kateşin, \%10 kafein, \%6 karbonhidrat, \%3 aminoasit ve \%1 TF'den oluştuğu rapor edilmiştir. Yapılan başka bir çalışmada bulgularımızı destekler nitelikte çay kremasında kafein oranının yaklaşık \%20 olduğu ifade edilmiştir. Aynı çalışmada yeşil çayda oluşan çay kremasının içeriğinin çayın elde edildiği taze çay yaprağ kısımlarına göre değişiklik gösterdiği belirlenmiş, çayın tomurcuğundan elde edilen çaydan oluşan kremadaki kateşin ve kafein içeriğinin dördüncü yapraktan elde edilen çayda oluşan kremadakine göre 10 kat fazla olduğu bildirilmiştir (Yin vd., 2009).
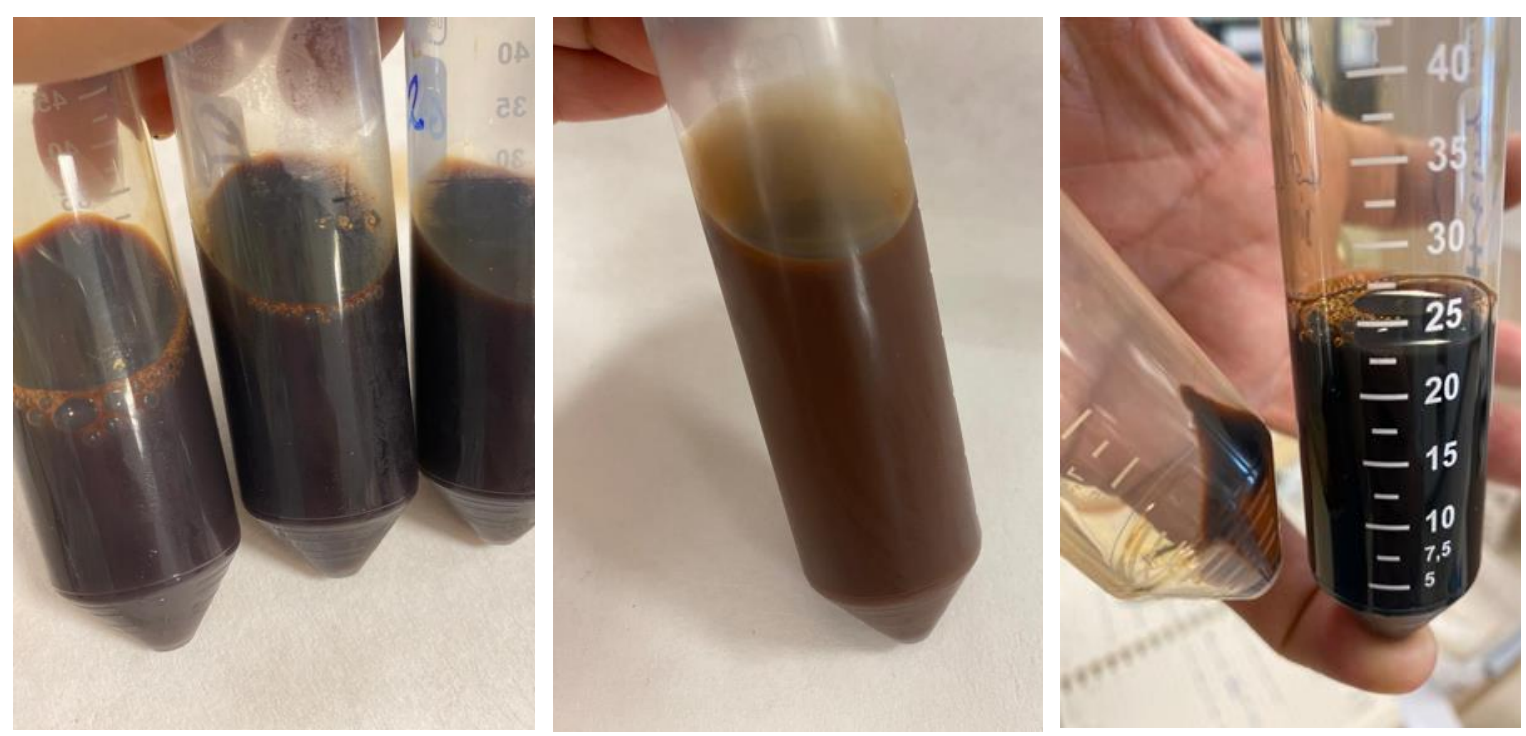

Şekil 2. Soğutulma sonrası kremalaşma ve kremanın ayrımı

Figure 2. Creaming after Cooling and Separation of Cream

Çizelge 4. Soğutma süresi sonrasında ekstraktlarda oluşan krema miktarı (g/100 mL) ve süpernatantların bulanıklık değerleri (NTU)

Table 4. The content of cream $(\mathrm{g} / 100 \mathrm{~mL})$ formed in the extracts after the cooling period and the turbidity values of the

\begin{tabular}{lcc}
\multicolumn{3}{c}{ supernatants } \\
\hline $\begin{array}{l}\text { Soğutma } \\
\text { (Saat) }\end{array}$ süresi & $\begin{array}{c}\text { Krema miktarl }(\mathrm{g} / 100 \mathrm{~mL}) \\
\text { Cooling time (Hour) }\end{array}$ & $\begin{array}{c}\text { Süpernatantm bulaniklik değeri (NTU) } \\
\text { Turbidity value of supernatant }(\mathrm{NTU})\end{array}$ \\
\hline 3 & $0.71 \pm 0.24^{\mathrm{c}}$ & $5.4 \pm 0.17^{\mathrm{a}}$ \\
6 & $1.51 \pm 0.57 \mathrm{~b}$ & $4.9 \pm 0.14^{\mathrm{ab}}$ \\
9 & $1.90 \pm 0.16^{\mathrm{ab}}$ & $4.3 \pm 0.21^{\mathrm{bc}}$ \\
12 & $1.98 \pm 0.36^{\mathrm{a}}$ & $3.4 \pm 0.28^{\mathrm{d}}$ \\
18 & $1.65 \pm 0.39^{\mathrm{ab}}$ & $4.0 \pm 0.11^{\mathrm{cd}}$ \\
24 & $1.60 \pm 0.28^{\mathrm{ab}}$ & $4.3 \pm 0.25^{\mathrm{bc}}$ \\
\hline
\end{tabular}

Sonuçlar Ortalama \pm Standart Hata olarak verilmiştir. Aynı sütundaki farklı harfler istatistiksel farkı ifade etmektedir $(P<0.05)$.

Values are given as Mean \pm Standard Error. Different letters in same column mean the statistical significance $(P<0.05)$. 
Çizelge 5. Çay kremasının bileşimi

Table 5. Composition of tea cream

\begin{tabular}{|c|c|c|c|c|}
\hline & $\begin{array}{c}\text { Kafein miktar1 }(\mathrm{g} / 100 \mathrm{~g} \\
\mathrm{KM}) \\
\text { Caffeine content }(\mathrm{g} / 100 \mathrm{~g} \\
\text { DM }\end{array}$ & $\begin{array}{c}\text { Protein miktar1 } \\
(\mathrm{g} / 100 \mathrm{~g} \mathrm{KM}) \\
\text { Protein content }(\mathrm{g} / 100 \\
\mathrm{g} D M)\end{array}$ & $\begin{array}{l}\mathrm{TF}(\%) \\
\mathrm{TF}(\%)\end{array}$ & $\begin{array}{l}\text { TR }(\%) \\
\text { TR }(\%)\end{array}$ \\
\hline $\begin{array}{l}\text { Çay kremas1 } \\
\text { Tea cream }\end{array}$ & $15.88 \pm 3.55$ & $17.08 \pm 2.18$ & $0.41 \pm 0.14$ & $22.44 \pm 1.64$ \\
\hline
\end{tabular}

Sonuçlar Ortalama \pm Standart Hata olarak verilmiştir.

$V$ alues are given as Mean \pm Standard Error

Siyah çayda, TF, TR, gallatlanmış kateşinler, EGC, metilksantinler ve proteinler çökmeye, kateşinler, gallik asit, karbonhidratlar ve aminoasitler ise supernatant kisminda kalmaya meyillidir. TF'lerde gözlenen yüksek kremleşme eğilimi, öncelikle moleküllerin kendi içinde birleşmesi ve siyah çayın içinde doğal olarak bulunan glikoz ve kalsiyumun etkisiyle de artmasına bağlı olduğu belirtilmiştir (Jöbstl vd., 2005). Buna bağlı olarak, saflaştırılmış kateşinler, çay polifenol oksitleri, metilksantinler ve proteinler, tespit edilen diğer bileşenlerden daha güçlü kremleşme afinitelerine sahiptirler ve büyük ölçüde çay kreması oluşumunda etkili olmaktadır (Lin vd., 2015).

Çizelge 4'de krema ayrımından sonra elde edilen ekstraktın bulanıklık değerleri verilmiştir. Çizelge incelendiğinde 12 saat bekleme süresi sonunda oluşan kremanın ayrılması sonrasında elde edilen ekstraktın bulanıklık değerinin 3.40 NTU olduğu görülmektedir. Başlangiçta 27.60 NTU olan bulanıklı değeri ön konsantrasyon sorasında 34.00 NTU'ya artmış ve bu değer krema ayrımı sonrasında kabul edilebilir ölçüde azaltılmıştır. Chandini vd. (2013) tarafindan yapilan bir çalışmada siyah çay ekstraktının bulanıklık değeri 25.23 NTU olarak belirlenmiş ve çay ekstraktında kabul edilebilir (tüketicinin gözle algilayamadığ1) bulanıklık değerinin 5 NTU'nun altında olması gerektiği bildirilmiştir.

Çizelge 3'de verilen kremanın kateşin kompozisyonu incelendiğinde kremada $\% 8.72$ epigallokateşin, \%5.89 epigallokateşin gallat, $\% 5.38$ kateşin gallat, \%4.04 epikateşin gallat, $\% 2.83$ gallokateşin, $\% 2.15$ epikateşin ve $\% 1.37$ kateşinden oluştuğu görülmektedir. Kremada bulunan toplam kateşin miktarı hesaplandığında kremanın yaklaşık \%30'unun kateşinlerden oluştuğu belirlenmiştir. Literatürde siyah çay kremasının \%18'inin kateşinlerden oluştuğu bildirilmiş (Lin vd., 2015) olup, çalışmamızda elde edilen sonuçlar bildirilenden daha yüksek bulunmuștur. $\mathrm{Bu}$ farklıllığ ekstraktın bileșimi ve krema oluşumu şartları ile ilişkilendirebilmek mümkündür.

\section{Konsantre siyah çay atığ1 ekstraktının bileşimi}

Krema ayrımı yapılan $15^{\circ} \mathrm{Bx}$ 'lik ekstrakt ticari üretim koşulları göz önünde bulundurularak mikrobiyolojik açıdan stabil depolanabileceği 65 ${ }^{\circ} \mathrm{Bx}$ değerine konsantre edilmiş ve elde edilen ekstraktın analiz edilen özellikleri Çizelge 2 ve Çizelge 3'de verilmiştir. Konsantre ekstraktın kafein miktarı $20.77 \mathrm{~g} / 100 \mathrm{~g} \mathrm{KM}$, TF değeri $\% 0.21$, TR değeri $\% 18.01$, bulanıklık değeri 3.93 NTU, epikateşin miktarı $14.21 \mathrm{~g} / 100 \mathrm{~g}$ KM, epigallokateşin miktarı $5.88 \mathrm{~g} / 100 \mathrm{~g}$ KM, epigallokateşin gallat miktar1 $4.97 \mathrm{~g} / 100 \mathrm{~g} \mathrm{KM}$, kateşin gallat $3.64 \mathrm{~g} / 100 \mathrm{~g} \mathrm{KM}$, kateşin 3.60 $\mathrm{g} / 100 \mathrm{~g} \mathrm{KM}$, epikateşin gallat $2.82 \mathrm{~g} / 100 \mathrm{~g} \mathrm{KM}$, gallokateşin $2.69 \mathrm{~g} / 100 \mathrm{~g} \mathrm{KM}$ ve gallik asit 0.75 g/100 g KM olarak belirlenmiştir. Konsantre siyah çay atığ1 ekstraktının kateşin profili incelendiğinde kuru maddedeki oransal artışa bağlı olarak her bir kateşinin konsantrasyonun artş göstermediği görülmüştür. Elde edilen bu sonuç kateşinlerin termal stabilitelerinin birbirlerinden farklı olması ile ilişkilendirilebilir. Lun-Su vd. (2003) tarafindan kateşinlerin farklı sıcaklıklardaki termal stabilitesinin araştırıldığ çalşsma sonucunda epikateşin ve epigallokateşinin 
termal stabiliteleri epigallokateşin gallata göre daha yüksek bulunmuştur.

\section{SONUÇ}

Siyah çay üretim miktarıyla dünyada ilk 5 ülke arasında yer alan ülkemizde üretilen çayın ihracat potansiyelinin arttırlması için yüksek kalitede yeni çay ürünlerinin üretilmesine, üretim sirasinda oluşan attkların katma değeri arttırılmış ürünlere dönüştürülerek değerlendirilmesine ve bu ürünlerin üretimine olanak sağlayan proseslerin geliştirilmesine ihtiyaç duyulmaktadır. Bu çalışma ile ülkemiz siyah çay atıklarından soğuk çay başta olmak üzere çay içerikli farklı ürünlerde kullanılması mümkün olan konsantre çay ekstraktı üretimi gerçekleştirilmiş, üretim aşamalarında oluşan krema ile oluşan kayıplar ve her bir aşamada elde edilen ekstraktın bazı özellikleri belirlenmiştir. Araştırma sonuçları Türk siyah çay işlem atıklarından kateşin ve kafein içeriğiyle çayı temsil eden konsantre çay elde edilebileceğini göstermiş, ancak krema ile ekstrakttaki kateşinlerin ve kafeinin önemli bir kısmının ayrıldığı da belirlenmiştir. Bu bakımdan daha nitelikli konsantre çay üretimi için krema ayrımı yerine oluşumunun engellenmesi ve oluşan kremanın değerlendirilmesine yönelik çalışmaların yapılması gerekliliği sonucuna ulaşılmıştır.

\section{ÇIKAR ÇATIŞMASI BEYANI}

$\mathrm{Bu}$ makalede yer alan yazarların ve kurumların arasında herhangi bir çıkar çatışmasının olmadığını beyan ederiz.

\section{YAZARLARIN KATKISI}

Ferhan BALCI TORUN, denemenin kurulmas1, analizlerinin yapılması, istatistik değerlendirme aşamalarında ve makalenin yazım sürecinde; Kübra Sultan ÖZDEMIR, analizlerin yapılması, istatistik değerlendirme aşamalarında ve makalenin yazım sürecinde; Rukiye MAVUŞ, örneklerin temininde, denemenin kurulmasında ve makalenin yazım sürecinde; Mehmet TORUN, denemenin kurulması, analizlerin yapilması, analiz sonuçlarının değerlendirilmesi ve makalenin yazım sürecinde katkıda bulunmuştur.

\section{KAYNAKLAR}

Argyle, I.S., Bird, M.R., 2015. Microfiltration of high concentration black tea streams for haze removal using polymeric membranes. Desalin Water Treat 53, 1516-1531.

Balci, F., Özdemir, F., 2016. Influence of shooting period and extraction conditions on bioactive compounds in Turkish green tea. Food Sci Techno 36, 737-743.

Chandini, S.K., Rao, L.J., Subramanian, R., 2013. Membrane Clarification of Black Tea Extracts. Food Bioprocess Technol 6, 1926-1943.

de Mejia, E.G., Ramirez-Mares, M.V., Puangpraphant, S., 2009. Bioactive components of tea: cancer, inflammation and behavior. Brain Behav Immun 23, 721-731.

Dubey, K.K., Janve, M., Ray, A., Singhal, R.S., 2020. Ready-to-Drink Tea, Trends in Non"alcoholic Beverages. Elsevier, pp. 101-140.

Evans, P.J., Bird, M.R., 2010. The role of black tea feed conditions upon ultrafiltration performance during membrane fouling and cleaning. J Food Process Eng 33, 309-332.

Fatima, M., Rizvi, S.I., 2011. Health beneficial effects of black tea. Biomedicine 31, 3-8.

Gürü, M., Icen, H., 2004. Obtaining of caffeine from Turkish tea fiber and stalk wastes. Bioresour Technol 94, 17-19.

Gürses, Ö.L. ve Artık, N. 1987. Çay Analiz Yöntemleri, Çaykur Yayını, No: 7, Çay İşletmeleri Genel Müdürlüğ̈̈, Ankara.

Jöbstl, E., Fairclough, J.P.A., Davies, A.P., Williamson, M.P., 2005. Creaming in Black Tea. J Agr Food Chem 53, 7997-8002.

Lin, X., Chen, Z., Zhang, Y., Luo, W., Tang, H., Deng, B., Deng, J., Li, B., 2015. Comparative characterisation of green tea and black tea cream: Physicochemical and phytochemical nature. Food Chem 173, 432-440.

Lun Su, Y., Leung, L.K., Huang, Y., Chen, Z.-Y., 2003. Stability of tea theaflavins and catechins. Food Chem 83, 189-195. 
Özdemir, F., 1992. Farklı kıvırma metotlarının üç sürgün dönemi çayin siyah çaya işlenmesinde uygulanma etkinliği ve üretilen siyah çaylarının baz1 fiziksel, kimyasal ve duyusal özellikleri. Atatürk Üniversitesi Fen Bilimleri Enstitüsü Gıda Bilimi ve Teknolojisi, Doktora Tezi, Erzurum, Türkiye, $151 \mathrm{~s}$.

Özdemir, F., Nadeem, H. Ş., Akdoğan, A., Dinçer, C., Topuz, A., 2018. Effect of altitude, shooting period, and tea grade on the catechins, caffeine, theaflavin, and thearubigin of Turkish black tea. Turk J Agric For, 42(5), 334-340, doi:10.3906/tar-1710-21.

Pou, K.J., Paul, S.K., Malakar, S., 2019. Industrial Processing of CTC Black Tea, Caffeinated and Cocoa Based Beverages. Elsevier, pp. 131-162.

Sen, G., Sarkar, N., Nath, M., Maity, S., 2020. Bioactive components of tea. Arch Food Nutr

Sci 4, 001-009.

Shalmashi, A., Abedi, M., Golmohammad, F., Eikani, M.H., 2010. Isolation of Caffeine From Tea Waste Using Subcritical Water Extraction. J Food Process Eng 33, 701-711.

Tajchakavit, S., Boye, J.I., Couture, R., 2001. Effect of processing on post-bottling haze formation in apple juice. Food Res Int 34, 415424.

Torun, M., Dincer, C., Topuz, A., Sahin-Nadeem, H., Ozdemir, F., 2015. Aqueous extraction kinetics of soluble solids, phenolics and flavonoids from sage (Salvia fruticosa Miller) leaves. J Food Sci Technol 52, 2797-2805.

Wang, H., Helliwell, K., 2000. Epimerisation of catechins in green tea infusions. Food Chem 70, 337-344.

Xu, Y.-Q., Chen, S.-Q., Yuan, H.-B., Tang, P., Yin, J.-F., 2012. Analysis of cream formation in green tea concentrates with different solid concentrations. J Food Sci Technol 49, 362-367.

Y1lmaz, C., Özdemir, F., Gökmen, V., 2020. Investigation of free amino acids, bioactive and neuroactive compounds in different types of tea and effect of black tea processing. LWT-Food Sci Technol 117, 108655.

Yin, J.-F., Xu, Y.-Q., Yuan, H.-B., Luo, L.-X., Qian, X.-J., 2009. Cream formation and main chemical components of green tea infusions processed from different parts of new shoots. Food Chem 114, 665-670.

Zhu, B., Chen, L.-B., Lu, M., Zhang, J., Han, J., Deng, W.-W., Zhang, Z.-Z., 2019. Caffeine Content and Related Gene Expression: Novel Insight into Caffeine Metabolism in Camellia Plants Containing Low, Normal, and High Caffeine Concentrations. J Agr Food Chem 67, 3400-3411. 